\title{
AGREEing on clinical practice guidelines for idiopathic steroid-sensitive nephrotic syndrome in children
}

Khalid Abdulaziz Alhasan ${ }^{1,2}$, Reem Al Khalifah³, Majed Aloufi, ${ }^{4,5}$, Weiam Almaimann, ${ }^{5,6}$, Muddathir Hamad , Naif Abdulmajeed ${ }^{8}$, Abdullah Al Salloum ${ }^{1}$, Jameela A. Kari ${ }^{9}$, Muneera AlJelaify ${ }^{10}$, Rolan K. Bassrawi ${ }^{11}$, Turki Al Hussain ${ }^{5,12}$, Adi Alherbish ${ }^{13}$, Abdulhadi Al Talhi ${ }^{14,15}$, Mohamad-Hani Temsah ${ }^{16}$, Sidharth Kumar Sethi ${ }^{17}$, Rupesh Raina ${ }^{18}$, Reny Joseph ${ }^{19}$, Yasser Sami Amer ${ }^{20,21,22,23^{*}}$ (D) and on behalf of the Saudi Society of Nephrology and Transplantation

\begin{abstract}
Background: Nephrotic syndrome is the most common kidney disease in children worldwide. Our aim was to critically appraise the quality of recent Clinical Practice Guidelines (CPGs) for idiopathic steroid-sensitive nephrotic syndrome (SSNS) in children in addition to summarize and compare their recommendations.

Methods: Systematic review of CPGs. We identified clinical questions and eligibility criteria and searched and screened for CPGs using bibliographic and CPG databases. Each included CPG was assessed by four independent appraisers using the Appraisal of Guidelines for REsearch \& Evaluation II (AGREE-II) instrument. We summarized the recommendations in a comparison practical table.
\end{abstract}

Results: Our search retrieved 282 citations, of which three CPGs were eligible and appraised: Kidney Disease: Improving Global Outcomes (KDIGO) 2012, Japan Society for Pediatric Nephrology (JSPN) 2014, and American Academy of Pediatrics (AAP) 2009. Among these, the overall assessment of two evidence-based CPGs scored $>70 \%$ (KDIGO and JSPN), which was consistent with their higher scores in the six domains of the AGREE II Instrument. In domain 3 (rigor of development), KDIGO, JSPN, and AAP scored 84\%, 74\%, and 41\%, respectively. In domain 5 (applicability), they scored 22\%, 16\%, and 19\%, respectively, and in domain 6 (editorial independence), they scored $94 \%, 65 \%$, and $88 \%$, respectively.

Conclusions: The methodological quality of the KDIGO CPG was superior, followed by JSPN and AAP CPGs with the relevant recommendations for use in practice.

Systematic review registration: The protocol was registered in the Center for Open Science (OSF) DOI: 10.17605/ OSF.IO/6QTMD and in the International prospective register of systematic reviews PROSPERO 2020 CRD420201 97511.

Keywords: Nephrotic syndrome, Pediatrics, Clinical practice guidelines, Systematic review, AGREE II Instrument, Quality assessment

\footnotetext{
* Correspondence: yamer@ksu.edu.sa; yassersamiamer@gmail.com

${ }^{20}$ Pediatrics Department, King Khalid University Hospital, Riyadh, Saudi Arabia

${ }^{21}$ Clinical Practice Guidelines Unit, Quality Management Department, King

Saud University Medical City, Riyadh, Saudi Arabia

Full list of author information is available at the end of the article
}

(c) The Author(s). 2021 Open Access This article is licensed under a Creative Commons Attribution 4.0 International License, which permits use, sharing, adaptation, distribution and reproduction in any medium or format, as long as you give appropriate credit to the original author(s) and the source, provide a link to the Creative Commons licence, and indicate if changes were made. The images or other third party material in this article are included in the article's Creative Commons licence, unless indicated otherwise in a credit line to the material. If material is not included in the article's Creative Commons licence and your intended use is not permitted by statutory regulation or exceeds the permitted use, you will need to obtain permission directly from the copyright holder. To view a copy of this licence, visit http://creativecommons.org/licenses/by/4.0/ The Creative Commons Public Domain Dedication waiver (http://creativecommons.org/publicdomain/zero/1.0/) applies to the data made available in this article, unless otherwise stated in a credit line to the data. 


\section{Background}

Nephrotic syndrome is considered the most common kidney disease in children worldwide. It is defined by a clinical characteristic of hypoalbuminemia $<25 \mathrm{~g} / \mathrm{L}$, edema and nephrotic range proteinuria $>40 \mathrm{mg} / \mathrm{m}^{2} / \mathrm{h}$, or protein/creatinine ratio $>200 \mathrm{mg} / \mathrm{mmol}$ in a spot urine sample $[1,2]$. There are many classifications of nephrotic syndrome: one of the classifications is based on the clinical response to steroids. Most children with nephrotic syndrome respond to steroids within 4 weeks of proper steroid therapy (i.e., steroid-sensitive nephrotic syndrome [SSNS]); however, these children behave differently afterward [3].

The Kidney Disease: Improving Global Outcomes (KDIGO) stated the important scientific definitions of nephrotic syndrome: Patients with steroid-dependent nephrotic syndrome (SDNS) are defined as patients who have relapse while weaning the steroid dose or within 14 days of steroid discontinuation. Frequently relapsing nephrotic syndrome (FRNS) is defined as two or more relapses in 6 months after the initial response or four and more relapses in any 1-year period [2].

The global incidence rate of nephrotic syndrome of childhood is variable among countries and ranges from 1.15 to 16.9 per 100,000 children annually $[4,5]$. Children with nephrotic syndrome require prolonged use of immunosuppressive agents, with multiple adverse effects, including infections and other side effects. A study conducted in a tertiary care center in Saudi Arabia by Alfakeeh et al. showed that the cumulative yearly dose of steroids is an important independent risk of infection [6].

In our practice, we noted center-to-center differences in managing patients diagnosed with SSNS, SDNS, and FRNS. The main differences we observed were in the duration of steroid therapy, steroid weaning, selection of second-line immunosuppressive agent and its targeted levels, and other practice parameters [7-9].

We would like to adapt a unified national evidencebased clinical practice guideline (CPG) for the management of these patients. Our aim from developing this CPG is to unify the practice between centers and improve patients' outcomes and experience.

CPGs are statements that include recommendations intended to optimize patient care that are informed by a systematic review (SR) of evidence and an assessment of the benefits and harms of alternative care options [10]. To date, there are no national CPGs to provide evidencebased guidance for healthcare professionals during the provision of clinical care for children with idiopathic SSNS in Saudi Arabia. In 2019, a decision was made to launch a project for adaptation of a national evidence-based CPG for the management of children with SSNS by the Department of Pediatrics, College of Medicine, King Saud University (KSU) in collaboration with the Saudi Society of Nephrology and Transplantation, as the governing body of nephrology including pediatric nephrology practice in Saudi Arabia, to provide guidance and recommendations to pediatricians, nephrologists, pharmacists, nurses, pathologists, children with SSNS, and all related stakeholders in Saudi Arabia who care for these children. The project is guided by the "KSU-Modified-ADAPTE" as a formal CPG adaptation methodology consisting of three phases: setup, adaptation, and finalization [11-13].

The Appraisal of Guidelines for REsearch \& Evaluation (AGREE II) instrument is the gold standard for the quality appraisal of CPGs. AGREE II is a validated CPG appraisal tool cited in $>1013$ articles and endorsed by several healthcare organizations [14-16]. AGREE II identifies components that should be addressed by CPGs to improve their quality and trustworthiness and obtain positive patient outcomes [11, 14-16].

Since the SR of CPGs, using AGREE II, is a key step in the CPG adaptation process, we have dedicated this study to report the results of this SR and critically appraise recently published CPGs for childhood SSNS using AGREE II $[11,17,18]$.

We utilized the PIPOH Model [i.e., Population (P), Intervention (I), Professionals $(\mathrm{P})$, Outcomes $(\mathrm{O})$, and Healthcare setting or context $(\mathrm{H})][11,12,17]$ where the Population $(P)$ included children aged 2-12 years with non-congenital, idiopathic SSNS, including new-onset nephrotic syndrome, SDNS, or FRNS without any comorbidities. Intervention(s) (I) included all pharmacological therapeutic agents. Professionals $(P)$ or target users of CPGs included mainly pediatric nephrologists, general pediatricians, and pharmacists and nurses with relevant nephrology experience. Outcomes $(O)$ included prevention of disease relapse, appropriateness of prescription (i.e., duration of steroid courses in newly diagnosed SSNS and drug of choice of the second agent in SDNS or FRNS). Healthcare settings or context $(H)$ included CPGs to be used in secondary and tertiary healthcare settings. The four main health questions were prioritized for this review. Additionally, we have utilized the PICAR statement where P: Population, clinical indication(s), and condition(s), I: Intervention(s), C: Comparator(s), Comparison(s), and (key) Content, A: Attributes of eligible CPGs, and R: Recommendation characteristics [17].

\section{Health questions}

1. Among children aged 2-12 years with noncongenital, idiopathic SSNS, what is the preferred and best effective treatment to prevent disease relapse?

2. Among children aged 2-12 years with SSNS, what is the appropriate steroid and duration of the steroid course in newly diagnosed children with SSNS?

3. Among children aged 2-12 years with FRNS or SDNS, what is the most appropriate drug as the second-line agent to induce disease remission? 
4. Among children aged 2-12 years with noncongenital, idiopathic SSNS, what is the preferred genetic testing to be conducted?

\section{Methods}

The protocol for this study was registered in PROSPERO (International Prospective Register of Systematic Reviews) (Protocol ID: CRD42020197511) and in the Center for Open Science (OSF) (DOI 10.17605/OSF.IO/6QTMD).

Our CPG working group included expert pediatric nephrologists, general pediatricians, a pediatric intensivist, a clinical pharmacist, a renal pathologist, and a specialized nurse guided by two pediatricians with expertise in CPG methodologies. Two external international experts in nephrology were invited as international collaborators to contribute to this CPG project.

\section{Data sources and search strategy}

We systematically searched MEDLINE and EMBASE databases for relevant guidelines using the Ovid platform and hand-searched EBSCO DynaMed Plus (USA), ECRI Guidelines Trust, Guidelines International Network, International Guideline Library, National Institute for Health and Care Excellence (UK), Scottish Intercollegiate Guidelines Network (UK), and Australian National Health and Medical Research Council (Australia). Moreover, we searched databases of national and international societies specializing in fields related to our health topic of SSNS, including the Japanese Society of Pediatric Nephrology (JSPN), KDIGO, International Society of Nephrology, American Society of Pediatric Nephrology, National Kidney Foundation, American Academy of Pediatrics (AAP), and Scottish Paediatric Renal and Urology Network. The search terms used included combinations of subject headings and keywords with various synonyms for idiopathic SSNS, nephrotic syndrome, nephrology, pediatrics, pediatric medicine, child health, treatment, management, pharmacology, practice guidelines, CPGs, healthcare quality, patient safety, evidence-based medicine, AGREE II instrument, quality assessment, critical appraisal, and evidence-based pediatrics (see search strategy in additional file 1). The search was limited to published or updated CPGs between January 1, 2009, and December 31, 2019. We have decided on the last 10 years as the cutoff for dates of publication because typically CPGs are updated every $2-5$ years [19]. The search was conducted by two CPG methodologists (RA and YA). We utilized the PIPOH model in addition to the PICAR statement (additional file 2) to support the CPG eligibility identification process $[11,12,17]$. Two reviewers (MA and AA) independently screened titles and abstracts of retrieved CPGs and articles meeting the inclusion criteria. The screening and full-text review were checked by three different reviewers $(\mathrm{MH}, \mathrm{AA}$, and $\mathrm{AA})$. Disagreements were resolved by focus group discussions after retrieving and reviewing the full-text articles or full CPG documents.

\section{Inclusion and exclusion criteria}

Teams of two reviewers, independently and in duplicate, screened titles and abstracts and potentially eligible full-text reports to determine eligibility. Disagreements were resolved through a review by RA. The eligibility criteria were as follows: (1) evidence-based with a clear record of their development methods; (2) English or Arabic language; (3) original source CPGs (de novo development); (4) national or international scope; and (5) published by an organization or group authorship and accessible from a CPG database or peer-reviewed journal. Only the most current version of each source CPG was appraised.

The exclusion criteria were CPGs that were published earlier than 2009, not in the English or Arabic language, adapted from other CPGs, presented as consensus or expert-based statements, or had a single author.

\section{AGREE II instrument workshop}

The two CPG methodologists (YA and RA) conducted a capacity building workshop for the review team through hands-on sessions in the concepts of evidence-based medicine and evidence-based CPG standards using the AGREE II instrument tool in 2 days. During the workshop, participants refined the research questions of interest to adapt a CPG to local practice (see the abovementioned health questions). Afterward, each reviewer scored his/her assigned CPGs. All four reviewers critically appraised each CPG. All appraisers reviewed the full CPG documents, including any updates with any relevant supplementary information or links to online web pages related to the CPG methods or CPG implementation tools. For each item, AGREE appraisers were instructed to record the justifications for their scores in the "Comment" section [20].

\section{Assessment of childhood SSNS CPGs using AGREE II}

The AGREE II instrument (www.agreetrust.org) consisted of 23 items organized into six domains: scope and purpose, stakeholder involvement, rigor of development, clarity of presentation, applicability, and editorial independence $[14,15]$. Each item was scored on a 7-point Likert scale. The AGREE II evaluation was guided by utilizing its online version: "My AGREE PLUS," which supports having a CPG appraisal group for each CPG that compiles and calculates the items' ratings into domain ratings and comments $[14,15]$. The four AGREE II appraisers for each CPG comprised a multidisciplinary group with expertise in pediatric nephrology (consultant physicians and head nurse) and pediatric clinical pharmacology (one clinical pharmacist), in addition to a general pediatrician with expertise in CPG methodologies. 
Wide discrepancies between the assessors' scores of items or questions (i.e., whenever there was a difference between these scores of $>3$ ) were resolved by discussion with the appraisal group. The online My AGREE PLUS automatically calculated the standardized AGREE domain scores or ratings (\%). We agreed upon a cutoff point of $70 \%$ for each AGREE standardized domain score or rating. After the appraisal, more weight was emphasized on the scores of domains 3 and 5 to facilitate the filtration and final evaluation of the reporting quality of included CPGs. Similar cutoff values were reported [21-23]. In addition to the classification of the six AGREE II domains, the evidence base of the included CPGs, their references' sections, was screened for SRs or meta-analyses, specifically Cochrane reviews.

\section{Analysis plan}

For each AGREE II domain, we calculated standardized scores ranging from 0 to $100 \%$ using the methods suggested by the AGREE II instrument. The key recommendations of the eligible CPGs were summarized in a comparative tabular format. The quality of CPGs was classified based upon the rating of domain 3 (rigour of development) where a high-quality CPG will receive a standardized domain rating of more than or equal to $70 \%$, moderate quality CPG (40$69 \%$ ), and low quality (less than 40\%).

\section{Results}

\section{Identification of CPGs for SSNS in children}

We retrieved a total of 282 records. After screening titles and abstracts, eight were included for full-text assessment, and only three were eligible for the review as illustrated in the PRISMA [24] flowchart (Fig. 1) and the PRISMA checklist (additional file 3). These CPGs were developed by the AAP [25], JSPN [26-28], and KDIGO-Chapter 3 [29]. At the time of writing this manuscript, the 2020 KDIGO "CPG on Glomerular Diseases" update was under development as the public review has just closed in the official KDIGO website [30]

\section{Key characteristics of childhood SSNS CPGs}

Table 1 highlights the characteristics of all eligible CPGs. The CPG developer organizations were reference, specialized professional organizations in pediatrics or nephrology, including KDIGO, AAP, and JSPN. All organizations were from high-income countries.

\section{Reporting the quality of Childhood SSNS CPGs}

The AGREE II standardized domain ratings are summarized in Table 2.

\section{Domain 1: scope and purpose}

The AGREE II standardized score for domain 1 ranged from 65 to $100 \%$. The scores of two CPGs were $>70 \%$ in domain $1(\mathrm{KDIGO}=100 \%$ and $\mathrm{AAP}=75 \%)$.

\section{Domain 2: stakeholder involvement}

The AGREE II standardized domain scores for domain 2 ranged from 60 to $86 \%$. The score of a single CPG was $>70 \%$ in domain $2(\mathrm{JSPN}=86 \%)$.

\section{Domain 3: rigor of development}

The AGREE II standardized scores for domain 3 ranged from 41 to $84 \%$. The score of two CPGs were $>70 \%$ in domain $3(\mathrm{KDIGO}=84 \%$ and $\mathrm{JSPN}=74 \%)$. They both reported utilizing the Grading of Recommendations,

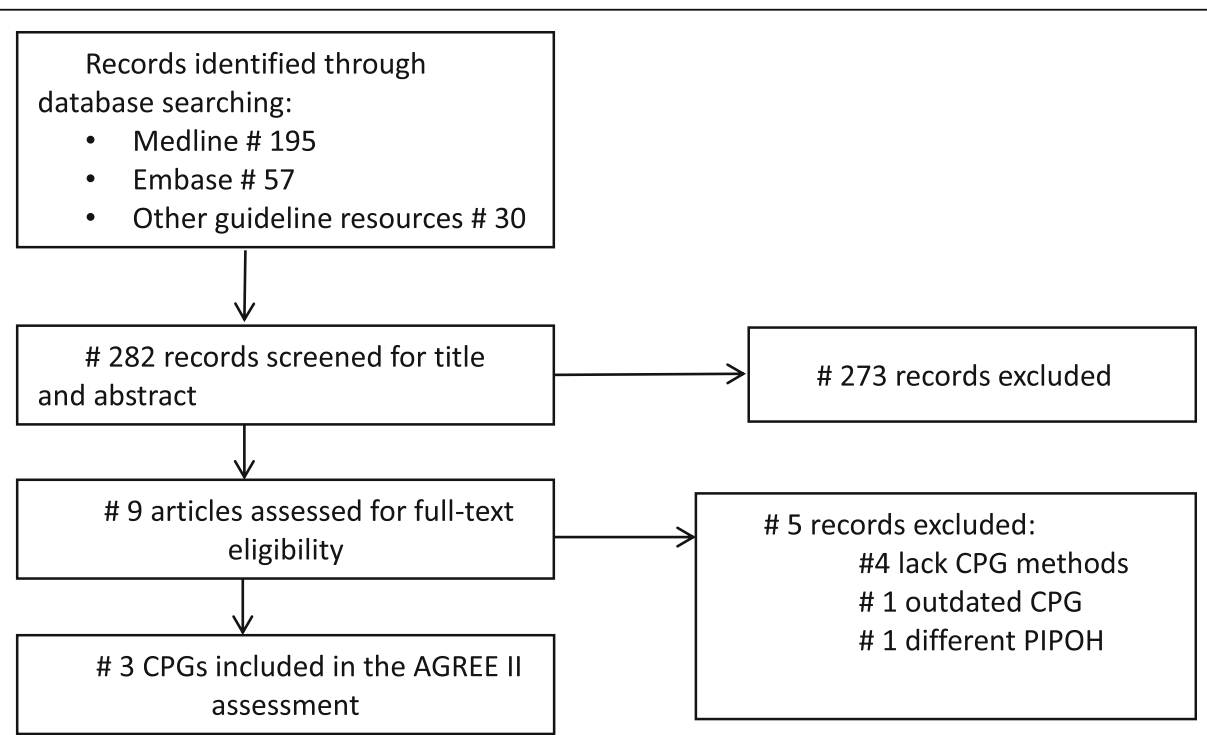

Fig. 1 Systematic search and selection of the clinical practice guidelines for management of idiopathic SSNS in children [Moher 2009]. For more information, visit www.prisma-statement.org 
Table 1 Characteristics of the included childhood SSNS CPGS

\begin{tabular}{lllll}
\hline Title & $\begin{array}{l}\text { Year of } \\
\text { publication }\end{array}$ & $\begin{array}{l}\text { Country } \\
\text { (economic level) }\end{array}$ & $\begin{array}{l}\text { Methods of } \\
\text { development }\end{array}$ & $\begin{array}{l}\text { Total number } \\
\text { of CSRs }\end{array}$ \\
\hline $\begin{array}{l}\text { AAP_Management of childhood onset nephrotic } \\
\text { syndrome }\end{array}$ & 2009 & USA (high-income country) & $\begin{array}{l}\text { Consensus-based } \\
\text { with literature review }\end{array}$ \\
$\begin{array}{l}\text { JSPN_Evidence-based clinical practice guidelines } \\
\text { for nephrotic syndrome }\end{array}$ & 2014 & Japan (high-income country) & MINDS, GRADE \\
$\begin{array}{l}\text { KDIGO_Clinical practice guideline for } \\
\text { glomerulonephritis_Chapter 3 }\end{array}$ & 2012 & International (not applicable) & GRADE
\end{tabular}

CPG clinical practice guideline; CSR Cochrane systematic review; GRADE Grading of Recommendations, Assessment, Development and Evaluations; MIND $S$ Medical Information Network Distribution Service

Assessment, Development and Evaluations method. Moreover, the KDIGO CPG reported its adherence to two sets of CPG standards, namely the Conference on Guideline Standardization Checklist for Reporting CPGs and the Institute of Medicine Standards for Systematic Reviews and Guidelines.

\section{Domain 4: clarity of presentation}

The AGREE II standardized scores for domain 4 ranged from 78 to $100 \%$. The scores of all three CPGs were $>70 \%$ in domain $4(\mathrm{AAP}=78 \%, \mathrm{JSPN}=90 \%, \mathrm{KDIGO}$ $=100 \%)$.

\section{Domain 5: applicability}

The AGREE II standardized scores for domain 5 ranged from 16 to $22 \%$. None of the included CPGs scored $>70 \%$.

\section{Domain 6: editorial independence}

The AGREE II standardized scores for domain 6 ranged from 65 to $94 \%$. The scores of two CPGs were $>70 \%$ in domain $6(\mathrm{AAP}=88 \%, \mathrm{KDIGO}=94 \%)$.

\section{Overall assessment}

The AGREE II standardized domain scores for the first overall assessment ranged from 58 to $75 \%$. Two CPGs scored $>70 \%$ (KDIGO and JSPN), which was consistent with the high scores in the six AGREE II domains.

\section{Recommending the childhood SSNS CPGs for use in practice}

The second (overall) assessment (i.e., recommendation for using the CPG in practice) revealed a consensus between the reviewers on recommending the use of two CPGs.

Table 2 AGREE II standardized domain scores for childhood SSNS CPGS

\begin{tabular}{|c|c|c|c|}
\hline CPGs/AGREE II domain-standardized scores (\%) & AAP 2009 [25] & JSPN 2014 [26-28] & KDIGO 2012 [29] \\
\hline $\begin{array}{l}\text { Domain 1. Scope and Purpose } \\
\text { Items 1-3: Objectives; Health question(s); Population (patients, public, etc.) }\end{array}$ & $75 \%$ & $65 \%$ & $100 \%$ \\
\hline $\begin{array}{l}\text { Domain 2. Stakeholder Involvement } \\
\text { Items 4-6: Group Membership; Target population preferences and views; } \\
\text { Target users }\end{array}$ & $60 \%$ & $86 \%$ & $64 \%$ \\
\hline $\begin{array}{l}\text { Domain 3. Rigor of development } \\
\text { Items 7-14: Search methods; Evidence selection criteria; Strengths and } \\
\text { limitations of the evidence; Formulation of recommendations; } \\
\text { Consideration of benefits and harms; Link between recommendations and } \\
\text { evidence; External review; Updating procedure. }\end{array}$ & $41 \%$ & $74 \%$ & $84 \%$ \\
\hline $\begin{array}{l}\text { Domain 4. Clarity and presentation } \\
\text { Items 15-17: Specific and unambiguous recommendations; Management } \\
\text { options; Identifiable key recommendations }\end{array}$ & $78 \%$ & $90 \%$ & $100 \%$ \\
\hline $\begin{array}{l}\text { Domain 5. Applicability } \\
\text { Items 18-21: Facilitators and barriers to application; Implementation } \\
\text { advice/ tools; Resource implications; Monitoring/auditing criteria }\end{array}$ & $19 \%$ & $16 \%$ & $22 \%$ \\
\hline $\begin{array}{l}\text { Domain 6. Editorial independence } \\
\text { Items 22, 23: Funding body; Competing interests }\end{array}$ & $88 \%$ & $65 \%$ & $94 \%$ \\
\hline $\begin{array}{l}\text { Overall Assessment } 1 \\
\text { (Overall quality) }\end{array}$ & $58 \%$ & $71 \%$ & $75 \%$ \\
\hline $\begin{array}{l}\text { Overall Assessment } 2 \\
\text { (Recommend the CPG for use by four appraisers) }\end{array}$ & $\begin{array}{l}\text { Yes }(n=0) \text {; } \\
\text { Yes with modifications ( } n \\
=3) \text {; } \\
\text { No }(n=1)\end{array}$ & $\begin{array}{l}\text { Yes }(n=1) \text {; } \\
\text { Yes with modifications ( } \\
=3) \\
\text { No }(n=0)\end{array}$ & $\begin{array}{l}\text { Yes }(n=2) \text {; } \\
\text { Yes with modifications ( } n \\
=2) \\
\text { No }(n=0)\end{array}$ \\
\hline
\end{tabular}


All included CPGs cited SRs in their reference list. The largest number of SR citations was observed in the JPNS CPG $(n=12)$, among them were six Cochrane SRs [26-28], followed by KDIGO-Chapter $3(n=5)$ including four Cochrane SRs [29], and lastly AAP $(n=4)$ with one Cochrane SR [25].

\section{Discussion}

Although several regional and national guidelines have been published [25-30], shared treatment guidelines are limited in Saudi Arabia, and consequently, physicians rely on the clinical expertise of each unit to select the best treatment option for pediatric patients with SSNS. To the best of our knowledge, this review is novel in that it systematically evaluates the quality of recently published CPGs of SSNS in children using the AGREE II instrument as a part of a national CPG adaptation initiative.

Three CPGs addressing the management of children with SSNS were assessed using the AGREE II instrument. This AGREE II assessment highlighted several areas of improvement in the methodological rigor of the included CPGs. Although the assessment of overall guideline quality and recommendation for use are standard components of AGREE II, it is possible that they are underreported: standardized domain scores for the first overall assessment ranged from 58 to $75 \%$, with the KDIGO and JSPN scoring $>70 \%$.

In this review, the scores of all three CPGs were > $70 \%$ in domain 4 . However, it was previously suggested that domain 3 was the strongest indicator of guideline quality than other domains [31-33], with a high score signifying a low degree of bias and evidence-based guideline development [33]. Conversely, a low score suggests serious methodological flaws. This may be the case, for example, if the team in charge of developing the guideline includes experts with little experience in guideline development or if the systematic search strategy is inadequately described [31].

A summary for the key recommendations of the three included CPGs is presented in Tables 3 and 4. A separate

Table 3 Summary comparison between the three included clinical practice guidelines for management of steroid-sensitive nephrotic syndrome in children): Case definition

\begin{tabular}{|c|c|c|c|}
\hline $\begin{array}{l}\text { Options of care } \\
\text { and management } \\
\text { of children with } \\
\text { SSNS }\end{array}$ & $\begin{array}{l}\text { AAP CPG } 2009 \text { [25] } \\
\text { Moderate-quality CPG (Domain 3: } \\
40-69 \%)\end{array}$ & $\begin{array}{l}\text { JSPN CPG } 2014 \text { [26-28] } \\
\text { High-quality CPG (Domain 3: } \geq 70 \% \text { ) }\end{array}$ & $\begin{array}{l}\text { KDIGO CPG } 2012 \text { [29] } \\
\text { High-quality CPG (Domain 3: } \geq 70 \% \text { ) }\end{array}$ \\
\hline \multicolumn{4}{|l|}{ Case definition } \\
\hline $\begin{array}{l}\text { - Nephrotic } \\
\text { syndrome }\end{array}$ & $\begin{array}{l}\text { A urine protein/creatinine ratio (Up/ } \\
\text { c) of } \geq 2 \text { and a serum albumin level } \\
\text { of } \leq 2.5 \mathrm{mg} / \mathrm{dL}\end{array}$ & $\begin{array}{l}\text { Severe proteinuria ( } \geq 40 \mathrm{mg} / \mathrm{m}^{2} / \mathrm{h} \text { in pooled night } \\
\text { urine) or early morning urine protein/creatinine } \\
\text { ratio } \geq 2.0 \mathrm{~g} / \mathrm{gCr} \text { and hypoalbuminemia (serum } \\
\text { albumin level } \leq 2.5 \mathrm{~g} / \mathrm{dL} \text { ) }\end{array}$ & $\begin{array}{l}\text { Presence of the following: } \\
\text { - Edema } \\
\text { - } \mathrm{uPCR} \geq 2000 \mathrm{mg} / \mathrm{g}(\geq 200 \mathrm{mg} / \mathrm{mmol}) \text { or } \geq 300 \\
\mathrm{mg} / \mathrm{dL} \text { or } 3+\text { protein on urine dipstick } \\
\text { - Hypoalbuminemia } \leq 2.5 \mathrm{~g} / \mathrm{dl}(\leq 25 \mathrm{~g} / \mathrm{L})\end{array}$ \\
\hline - Remission & $\begin{array}{l}\text { Up/c }<0.2 \text { or Albustix-negative } \\
\text { (Albustix, Miles, Inc, Diagnostics Div- } \\
\text { ision, Elkhart, IN) or trace for } 3 \text { days }\end{array}$ & $\begin{array}{l}\text { - Complete } \\
\text { Negative protein on dipstick testing of early } \\
\text { morning urine for } 3 \text { consecutive days or early } \\
\text { morning urine protein/creatinine ratio }<0.2 \mathrm{~g} / \mathrm{gCr} \\
\text { for } 3 \text { consecutive days } \\
\text { - Incomplete } \\
\geq 1+\text { protein on dipstick testing of early morning } \\
\text { urine or early morning urine protein creatinine ratio } \\
\geq 0.2 \mathrm{~g} / \mathrm{gCr} \text { and serum albumin }>2.5 \mathrm{~g} / \mathrm{dL}\end{array}$ & $\begin{array}{l}\text { - Complete remission: uPCR }<200 \mathrm{mg} / \mathrm{g}(<20 \\
\mathrm{mg} / \mathrm{mmol}) \text { or }<1+\text { of protein on urine } \\
\text { dipstick for } 3 \text { consecutive days } \\
\text { - Partial remission: Proteinuria reduction } \geq \\
50 \% \text { from the presenting value and absolute } \\
\text { uPCR between } 200 \text { and } 2000 \mathrm{mg} / \mathrm{g}(20-200 \\
\mathrm{mg} / \mathrm{mmol})\end{array}$ \\
\hline - Relapse & $\begin{array}{l}\text { After remission, an increase in the } \\
\text { first morning Up/c to } \geq 2 \text { or Albustix } \\
\text { reading of } \geq 2 \text { for } 3 \text { of } 5 \text { consecutive } \\
\text { days }\end{array}$ & $\begin{array}{l}\geq 3+\text { protein on dipstick testing of early morning } \\
\text { urine for } 3 \text { consecutive days }\end{array}$ & $\begin{array}{l}\mathrm{uPCR} \geq 2000 \mathrm{mg} / \mathrm{g} \text { ( } \geq 200 \mathrm{mg} / \mathrm{mmol} \text { ) or } \geq 3+ \\
\text { protein on urine dipstick for } 3 \text { consecutive days }\end{array}$ \\
\hline - FRNS & $\begin{array}{l}\text { Two or more relapses within } 6 \\
\text { months after initial therapy or four or } \\
\text { more relapses in any } 12 \text {-month } \\
\text { period }\end{array}$ & $\begin{array}{l}\text { Two or more relapses within } 6 \text { months after initial } \\
\text { remission or four or more relapses within any } 12 \\
\text { consecutive months }\end{array}$ & $\begin{array}{l}\text { Two or more relapses within } 6 \text { months of initial } \\
\text { response or four or more relapses in any } 12- \\
\text { month period }\end{array}$ \\
\hline - SDNS & $\begin{array}{l}\text { Relapse during taper or within } 2 \\
\text { weeks of discontinuation of steroid } \\
\text { therapy. }\end{array}$ & $\begin{array}{l}\text { Two consecutive relapses during prednisolone } \\
\text { tapering or within } 14 \text { days after discontinuation of } \\
\text { prednisolone }\end{array}$ & $\begin{array}{l}\text { Two consecutive relapses during corticosteroid } \\
\text { therapy or within } 14 \text { days of therapy } \\
\text { discontinuation }\end{array}$ \\
\hline - SRNS & $\begin{array}{l}\text { Inability to induce a remission with } 4 \\
\text { weeks of daily steroid therapy }\end{array}$ & $\begin{array}{l}\text { Absence of complete remission after at least } 4 \\
\text { weeks of daily prednisolone therapy }\end{array}$ & $\begin{array}{l}\text { No remission after a minimum of } 8 \text { weeks } \\
\text { treatment with corticosteroids }\end{array}$ \\
\hline Genetic testing & Not mentioned & $\begin{array}{l}\text { - Useful in genetic illnesses } \\
\text { (type of testing not mentioned) }\end{array}$ & Not mentioned \\
\hline
\end{tabular}

AAP American Academy of Pediatrics; CPGs clinical practice guidelines; CNI calcineurin inhibitor; CPG ID short identity or acronym; JSPN Japanese Society of Paediatric Nephrology; CNIs KDIGO, Kidney Disease: Improving Global Outcomes; AAP 2009 CPG Management of childhood onset nephrotic syndrome; JPNS 2014 CPG evidence-based clinical practice guidelines for nephrotic syndrome; KDIGO 2012 CPG clinical practice guideline for glomerulonephritis-Chapter 3; ISKDC International Study of Kidney Disease in Children; MCNS minimal change nephrotic syndrome; MMF mycophenolate mofetil; FRNS Frequently relapsing nephrotic syndrome; SSNS steroid-sensitive nephrotic syndrome; SDNS steroid-dependent nephrotic syndrome; SRNS: steroid resistant nephrotic syndrome 
Table 4 Summary comparison between the three included clinical practice guidelines for management of steroid-sensitive nephrotic syndrome in children): Treatment

\begin{tabular}{|c|c|c|c|}
\hline $\begin{array}{l}\text { Options of care and } \\
\text { management of children } \\
\text { with SSNS }\end{array}$ & $\begin{array}{l}\text { AAP CPG } 2009 \text { [25] } \\
\text { Moderate-quality CPG (Domain 3: 40- } \\
69 \% \text { ) }\end{array}$ & $\begin{array}{l}\text { JSPN CPG } 2014 \text { [26-28] } \\
\text { High-quality CPG (Domain 3: } \geq 70 \% \text { ) }\end{array}$ & $\begin{array}{l}\text { KDIGO CPG } 2012[29] \\
\text { High-quality CPG (Domain 3: } \geq 70 \% \text { ) }\end{array}$ \\
\hline Diet therapy & $\begin{array}{l}\text { - Low-fat diet: limit dietary fat to }<30 \% \\
\text { of calories, saturated fat to }<10 \% \text { of } \\
\text { calories, and }<300 \mathrm{mg} / \text { day dietary } \\
\text { cholesterol. } \\
\text { - Low-sodium diet } \\
\text { (LoE: Not applicable, GoR: Opinion- } \\
\text { based) }\end{array}$ & $\begin{array}{l}\text { - Sodium restrictions for remission of } \\
\text { edema (Not Graded) } \\
\text { - The degree of sodium restrictions should } \\
\text { be determined based on the status of } \\
\text { edema and amount of food intake. } \\
\text { - Base protein consumption on the } \\
\text { nutrient requirement for healthy children } \\
\text { of the same age } \\
\text { Base the caloric energy intake on the age } \\
\text { of the patient }\end{array}$ & Not mentioned \\
\hline
\end{tabular}

Treatment of initial episode of SSNS with corticosteroids
- Prednisone $2 \mathrm{mg} / \mathrm{kg}$ per day for 6 weeks (maximum: $60 \mathrm{mg}$ ); then - Prednisone $1.5 \mathrm{mg} / \mathrm{kg}$ on alternate days for 6 weeks (maximum: $40 \mathrm{mg}$ ).

- No steroid taper is required at the conclusion of this initial therapy. (LoE Not applicable, GoR: Opinion-based)

Treatment of relapsing SSNS with corticosteroids
- Prednisone $2 \mathrm{mg} / \mathrm{kg}$ per day until urine protein test results are negative or trace for 3 consecutive days; then -Prednisone $1.5 \mathrm{mg} / \mathrm{kg}$ on alternate days for 4 weeks

(LoE: Not applicable, GoR: Opinionbased)
Corticosteroid therapy in Frequently relapsing SSNS

frequently relapsing (FR) - Prednisone $2 \mathrm{mg} / \mathrm{kg} /$ day unti and steroid-dependent (SD) SSNS in children proteinuria normalizes for 3 days, $1.5 \mathrm{mg} /$ $\mathrm{kg}$ on alternate days for 4 weeks, and then taper over 2 months by $0.5 \mathrm{mg} / \mathrm{kg}$ on alternate days (total: 3-4 months). (LoE: Not applicable, GoR: Opinionbased)

Steroid-dependent SSNS

- Glucocorticoids are preferred in the absence of significant steroid toxicity. - Secondary alternatives should be selected based on risk/benefit ratio. (LoE: Not applicable, GoR: Opinion-based)

Treatment of FR and SD SSNS with corticosteroid-sparing agents

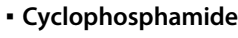

\section{Frequently relapsing SSNS}

Oral cyclophosphamide $2 \mathrm{mg} / \mathrm{kg} /$ day for 12 weeks (cumulative dose: $168 \mathrm{mg} / \mathrm{kg}$ ) based on ideal body weight started during prednisone ( $2 \mathrm{mg} / \mathrm{kg} /$ day) induced remission, decrease prednisone dose to $1.5 \mathrm{mg} / \mathrm{kg}$ on alternate days for 4 weeks, and then taper over 4 weeks. (LoE: Not applicable, GoR: Opinionbased)
- ISKDC regimen: Prednisolone for 8 weeks (Grade B):

$1.60 \mathrm{mg} / \mathrm{m}^{2} /$ day or $2.0 \mathrm{mg} / \mathrm{kg} /$ day in three divided doses daily for 4 weeks (maximum: $60 \mathrm{mg} /$ day), followed by 2. $40 \mathrm{mg} / \mathrm{m}^{2}$ or $1.3 \mathrm{mg} / \mathrm{kg}$ once in the morning on alternate days for 4 weeks (maximum: $40 \mathrm{mg}$ on alternate days). - Long-term, tapering regimen: prednisolone for 3-7 months

\section{- Modified ISKDC regimen}

1. $60 \mathrm{mg} / \mathrm{m}^{2} /$ day or $2.0 \mathrm{mg} / \mathrm{kg} /$ day in three divided doses daily until

confirmation of the resolution of proteinuria for at least 3 days but not exceeding 4 weeks (maximum: 60 mg/ day), followed by

2. $60 \mathrm{mg} / \mathrm{m}^{2}$ or $2.0 \mathrm{mg} / \mathrm{kg}$ once in the morning on alternate days for 2 weeks (maximum: $60 \mathrm{mg}$ on alternate days), followed by

$3.30 \mathrm{mg} / \mathrm{m}^{2}$ or $1.0 \mathrm{mg} / \mathrm{kg}$ once in the morning on alternate days for 2 weeks (maximum: $30 \mathrm{mg}$ on alternate days), followed by 4. $15 \mathrm{mg} / \mathrm{m}^{2}$ or $0.5 \mathrm{mg} / \mathrm{kg}$ once in the morning on alternate days for 2 weeks (maximum: 15 mg on alternate days). - Long-term, tapering regimen Should be selected when appropriate. (Not Graded)

Use immunosuppressive agents (e.g. cyclosporine, cyclophosphamide) in the treatment of frequently relapsing and steroid-dependent nephrotic syndrome (Grade C1) due to the development of various steroid-induced side effects.

- To be given at an initial dose of 2-2.5 mg/kg/day (maximum: 100 mg) and then once daily for 8-12 weeks. (Grade (1)

- A second course of cyclophosphamide should not be given and that cumulative doses do not exceed 300 $\mathrm{mg} / \mathrm{kg}$.
Oral prednisone or prednisolone as a single daily dose (1B) starting:

- Daily: $60 \mathrm{mg} / \mathrm{m}^{2} /$ day or $2 \mathrm{mg} / \mathrm{kg} /$ day to a maximum $60 \mathrm{mg} /$ day (1D) for 4-6 weeks (1C)

\section{then}

Alternate day: $40 \mathrm{mg} / \mathrm{m}^{2}$ or $1.5 \mathrm{mg} / \mathrm{kg}$ to a maximum $40 \mathrm{mg}$ (1D) for $2-5$ months with tapering of the dose (1B)

Initially: Prednisone as a single daily dose $60 \mathrm{mg} / \mathrm{m}^{2}$ or $2 \mathrm{mg} / \mathrm{kg}$ (maximum: $60 \mathrm{mg} /$ day) until the child has been in complete remission for at least 3 days (2D)

Then: Prednisone as a single dose on alternate days ( $40 \mathrm{mg} / \mathrm{m}^{2}$ per dose or 1.5 $\mathrm{mg} / \mathrm{kg}$ per dose: maximum $40 \mathrm{mg}$ on alternate days) for at least 4 weeks (2C)
- Initially: daily prednisone until the child has been in remission for at least 3 days - Then: alternate-day prednisone for at least 3 months. (2C)

Long term steroid: prednisone to be given on alternate days in the lowest dose to maintain remission without major adverse effects. (2D) If not effective: daily prednisone at the lowest dose to be given to maintain remission without major adverse effects (2D)

Use: as corticosteroid-sparing agent. (1B) for FR and (2C) for SD SSNS

Dose: $2 \mathrm{mg} / \mathrm{kg} /$ day to be given for $8-12$ weeks (maximum cumulative dose 168 $\mathrm{mg} / \mathrm{kg}$ ). (2C)

Timing: Not to be started until the child has achieved remission with corticosteroids. (2D)

Repeated courses: second courses of alkylating agents should not be 
Table 4 Summary comparison between the three included clinical practice guidelines for management of steroid-sensitive nephrotic syndrome in children): Treatment (Continued)

\begin{tabular}{|c|c|c|c|}
\hline $\begin{array}{l}\text { Options of care and } \\
\text { management of children } \\
\text { with SSNS }\end{array}$ & $\begin{array}{l}\text { AAP CPG } 2009 \text { [25] } \\
\text { Moderate-quality CPG (Domain 3: 40- } \\
69 \% \text { ) }\end{array}$ & $\begin{array}{l}\text { JSPN CPG } 2014 \text { [26-28] } \\
\text { High-quality CPG (Domain 3: } \geq 70 \% \text { ) }\end{array}$ & $\begin{array}{l}\text { KDIGO CPG } 2012[29] \\
\text { High-quality CPG (Domain 3: } \geq 70 \% \text { ) }\end{array}$ \\
\hline & $\begin{array}{l}\text { Steroid-dependent SSNS } \\
\text { - Oral cyclophosphamide } 2-3 \mathrm{mg} / \mathrm{kg} / \\
\text { day for } 8-12 \text { weeks. } \\
\text { - Given the severity of } \\
\text { cyclophosphamide-associated adverse } \\
\text { events, cytotoxic agents are considered a } \\
\text { third-line choice for steroid-dependent } \\
\text { nephrotic syndrome therapy. (LoE: Not } \\
\text { applicable, GoR: Opinion-based) }\end{array}$ & & administered. (2D) \\
\hline
\end{tabular}

\section{- Mycophenolate mofetil (MMF)}

- Levamisole

- Cyclosporine

- Mizoribine

- Tacrolimus

\section{Frequently relapsing SSNS}

Mycophenolate mofetil $25-36$ mg/kg/day (maximum: $2 \mathrm{~g} /$ day) in two divided doses for 1-2 years with a tapering dose of prednisone.

(LoE: Not applicable, GoR: Opinionbased)

\section{Steroid-dependent SSNS}

Mycophenolate mofetil 24-36 mg/kg/day or $1200 \mathrm{mg} / \mathrm{m}^{2} /$ day in two divided doses (maximum: 2 g/day). (LoE: Not applicable, GoR: Opinion-based)

Use of levamisole may reduce the risk of relapses without glucocorticoids. (LoE Not applicable, GoR: Opinion-based)

\section{Frequently relapsing SSNS}

- Cyclosporine A 3-5 mg/kg/day in two divided doses for an average of $2-5$ years.

- The nephrotoxic effects of cyclosporine warrant careful monitoring of kidney function and blood drug levels.

- The risk for nephrotoxicity attributable to calcineurin inhibitors makes this a third line option for frequently relapsing nephrotic syndrome.

(LoE: Not applicable, GoR: Opinionbased)

\section{Steroid-dependent SSNS}

Cyclosporine A 3-5 mg/kg/day in two

divided doses.

(LoE: Not applicable, GoR: Opinionbased)

Use of mizoribine (not available in the USA) may reduce the risk of relapses without glucocorticoids.

(LoE: Not applicable, GoR: Opinionbased)

\section{Frequently relapsing SSNS}

- Tacrolimus, an alternative calcineurin inhibitor, provides no advantage regarding nephrotoxicity profile. - The risk for nephrotoxicity attributable to calcineurin inhibitors makes this a third-line option for frequently relapsing nephrotic syndrome.

(LoE: Not applicable, GoR: Opinionbased)

\section{Steroid-dependent SSNS}

Tacrolimus 0.05 to $0.1 \mathrm{mg} / \mathrm{kg} /$ day in two divided doses.

(LoE: Not applicable, GoR: Opinion-

based)
- To be considered when standard immunosuppressive agents cannot be used because of their side effects (Grade (1)

- A dose of $1000-1200 \mathrm{mg} / \mathrm{m}^{2} /$ day or 24

36 mg/kg/day (maximum 2 g/day) be

administered in two divided doses
Use: as corticosteroid-sparing agent (2C) Dose: $1200 \mathrm{mg} / \mathrm{m}^{2} /$ day in two divided doses (2C)

Duration: at least 12 months (2C)
Not mentioned

To be given at an initial dose of 2.5-5 $\mathrm{mg} / \mathrm{kg} /$ day in two divided doses, followed by dose adjustment according to monitoring of blood drug concentration

(Grade C1)

- Not administered at the standard dose (4 mg/kg/day, maximum 150 mg/day) as it would be inadequately effective.

(Grade C1)

To be administered at higher doses of $7-$ $10 \mathrm{mg} / \mathrm{kg} /$ day once daily, with a peak blood mizoribine concentration ( $\mathrm{C} 2{ }^{* 2}$ or $\left(3^{* 3}\right) \geq 3.0 \mu \mathrm{g} / \mathrm{mL}$, because of reported efficacy in preventing relapses

- To be considered when cyclosporine cannot be used because of its cosmetic side effects.

Starting dose $(0.1 \mathrm{mg} / \mathrm{kg} /$ day) should be administered in two divided doses, followed by dose adjustment according to monitoring of blood drug concentration
Use: as corticosteroid-sparing agent. (1B) Dose: $2.5 \mathrm{mg} / \mathrm{kg}$ on alternate days (2B) Duration: at least 12 months (2C)

Use: as corticosteroid-sparing agent (1C) Dose: $4-5$ mg/kg/day in two divided doses. (2C)

Monitoring: Monitor CNI levels during therapy to limit toxicity. (Not Graded) Duration: at least 12 months. (2C)
Not to be used as corticosteroid sparing agent. (2C)

Use: To be used instead of cyclosporine when the cosmetic side effects of cyclosporine are unacceptable (as corticosteroid-sparing agent). (2D) Dose: $0.1 \mathrm{mg} / \mathrm{kg} /$ day administered in two divided doses (2D) Monitoring: Monitor CNI levels during therapy to limit toxicity. (Not Graded) Duration: at least 12 months (2C) 
Table 4 Summary comparison between the three included clinical practice guidelines for management of steroid-sensitive nephrotic syndrome in children): Treatment (Continued)

\begin{tabular}{|c|c|c|c|}
\hline $\begin{array}{l}\text { Options of care and } \\
\text { management of children } \\
\text { with SSNS }\end{array}$ & $\begin{array}{l}\text { AAP CPG } 2009 \text { [25] } \\
\text { Moderate-quality CPG (Domain 3: 40- } \\
69 \% \text { ) }\end{array}$ & $\begin{array}{l}\text { JSPN CPG } 2014 \text { [26-28] } \\
\text { High-quality CPG (Domain 3: } \geq 70 \% \text { ) }\end{array}$ & $\begin{array}{l}\text { KDIGO CPG } 2012 \text { [29] } \\
\text { High-quality CPG (Domain 3: } \geq 70 \% \text { ) }\end{array}$ \\
\hline - Chlorambucil & $\begin{array}{l}\text { Frequently relapsing SSNS } \\
\text { Compared with cyclophosphamide, } \\
\text { chlorambucil is associated with a slightly } \\
\text { greater toxicity profile and no } \\
\text { improvement in efficacy. } \\
\text { (LoE: Not applicable, GoR: Opinion- } \\
\text { based) } \\
\text { Steroid-dependent SSNS: } \\
\text { Chlorambucil may reduce the risk of } \\
\text { relapses without glucocorticoids. }\end{array}$ & Not mentioned & $\begin{array}{l}\text { Use: as corticosteroid-sparing agent. (1B) } \\
\text { for FR and ( } 2 \text { C) for SD SSNS } \\
\text { Dose } 0.1-0.2 \mathrm{mg} / \mathrm{kg} / \text { day may be } \\
\text { administered for } 8 \text { weeks (maximum } \\
\text { cumulative dose } 11.2 \mathrm{mg} / \mathrm{kg} \text { ) as an } \\
\text { alternative to cyclophosphamide. (2C) } \\
\text { Repeated courses: second courses of } \\
\text { alkylating agents should not be } \\
\text { administered (2D) }\end{array}$ \\
\hline
\end{tabular}

- Rituximab Not mentioned

Indication for kidney biopsy

Vaccination in children with SSNS
- Immunize with the 23-valent and heptavalent conjugated pneumococcal vaccines.

- Immunize the immunosuppressed or actively nephrotic patient and household contacts with inactivated influenza vaccine yearly.

- Defer immunization with live vaccines:

- Until prednisone dose is $<2 \mathrm{mg} / \mathrm{kg} /$ day (maximum: $20 \mathrm{mg}$ ).

- For 3 months from completion of therapy with cytotoxic agents or for 1 month from completion of other daily immunosuppression.

- Provide varicella immunization if nonimmune based on immunization history, disease history, or serologic evaluation.

- Provide postexposure immunoglobulin for nonimmune immunocompromised patients.

- Consider intravenous acyclovir for immunosuppressed children at the onset of chicken pox lesions.

(LoE: Not applicable, GoR: Opinionbased)
- To be considered only in refractory disease

- To be administered at a starting dosage of $375 \mathrm{mg} / \mathrm{m}^{2}$ per dose by intravenous drip infusion, administered one to four times (at 1-week intervals for multiple infusions) (Grade C1)

- At the onset of nephrotic syndrome in patients: (Not Graded):

1. Whose age is $<1$ year

2. With persistent hematuria and frank

hematuria

3. Hypertension and renal dysfunction

4. Hypocomplementemia

5. Extrarenal symptoms (e.g., rash, purpura), since these patients are likely to have other histological types than minimal-change disease.

- In patients showing steroid resistance

- In patients given long-term calcineurin inhibitor therapy, even without renal dysfunction (at 2-3 years into the therapy)

- Perform immunizations, when applicable. - Not use live attenuated vaccines in patients during steroid or immunosuppressant treatment.

- Attenuated vaccines may be determined on a case-by-case basis and according to the condition of the patient and epidemic (Grade B)

- Proactive vaccination to the family member of the patient if there is no history or vaccination against the prevalent infection prophylaxis with antiviral drugs (acyclovir or valaciclovir) in cases where the household has been in close contact with varicella
Use: to be considered only in children with SD SSNS who have continuing frequent relapses despite optimal combinations of prednisone and corticosteroid- sparing agents and/or who have serious adverse effects of therapy. (2C)

Indications for kidney biopsy in children with SSNS are (Not Graded):

- Late failure to respond following initial response to corticosteroids

- A high index of suspicion for a different underlying pathology

- Decreasing kidney function in children receiving CNIs

\section{To reduce the risk of serious} infections in children with SSNS (Not Graded):

- Provide pneumococcal vaccination to the children

- Provide influenza vaccination annually to the children and their household contacts.

- Defer vaccination with live vaccines until prednisone dose is below either 1 $\mathrm{mg} / \mathrm{kg}$ daily (<20 mg/day) or $2 \mathrm{mg} / \mathrm{kg}$ on alternate days $(<40 \mathrm{mg}$ on alternate days).

- Live vaccines are contraindicated in children receiving corticosteroid-sparing immunosuppressive agents.

- Immunize healthy household contacts with live vaccines to minimize the risk of transfer of infection to the immunosuppressed child but avoid direct exposure of the child to gastrointestinal, urinary, or respiratory secretions of vaccinated contacts for 3-6 weeks after vaccination.

- Following close contact with varicella infection, administer varicella zoster immune globulin, if available, to nonimmune children on immunosuppressive agents

- Fig. 1. Flowchart for the determination of treatment plan [27]

- Table 5. Examination findings of primary
Translations into four languages: Japanese, German, Russian, and Turkish. The Canadian Society of Nephrology 
Table 4 Summary comparison between the three included clinical practice guidelines for management of steroid-sensitive nephrotic syndrome in children): Treatment (Continued)

\begin{tabular}{|c|c|c|c|}
\hline $\begin{array}{l}\text { Options of care and } \\
\text { management of children } \\
\text { with SSNS }\end{array}$ & $\begin{array}{l}\text { AAP CPG } 2009 \text { [25] } \\
\text { Moderate-quality CPG (Domain 3: 40- } \\
69 \% \text { ) }\end{array}$ & $\begin{array}{l}\text { JSPN CPG } 2014 \text { [26-28] } \\
\text { High-quality CPG (Domain 3: } \geq 70 \% \text { ) }\end{array}$ & $\begin{array}{l}\text { KDIGO CPG } 2012[29] \\
\text { High-quality CPG (Domain 3: } \geq 70 \% \text { ) }\end{array}$ \\
\hline & & $\begin{array}{l}\text { nephrotic syndrome [26] } \\
\text { - Fig. 1. Treatment of MCNS [26] } \\
\text { - Table 1. Diuretic agents available for } \\
\text { infants/children [28] } \\
\text { - Table 2. 2Dietary reference intake for } \\
\text { Japanese population [28] } \\
\text { - Table 3. Health classification by the } \\
\text { status of nephrotic syndrome [28] }\end{array}$ & $\begin{array}{l}\text { published a Commentary in } 2014 \text { on the } \\
\text { KDIGO } 2012 \text { CPG (management of } \\
\text { nephrotic syndrome in children) } \\
\text { including the relevancy and applicability } \\
\text { of the recommendations to the Canadian } \\
\text { context. }\end{array}$ \\
\hline
\end{tabular}

AAP American Academy of Pediatrics; CPGs clinical practice guidelines; CNI calcineurin inhibitor; CPG ID short identity or acronym; GoR grade of recommendation; JSPN Japanese Society of Paediatric Nephrology; KDIGO Kidney Disease: Improving Global Outcomes; LoE Level (or quality) of evidence; FRNS Frequently relapsing nephrotic syndrome, SSNS steroid-sensitive nephrotic syndrome; $A A P 2009$ CPG management of childhood onset nephrotic syndrome; JPNS 2014 CPG evidence-based clinical practice guidelines for nephrotic syndrome; KDIGO 2012 CPG clinical practice guideline for glomerulonephritis-Chapter 3; ISKDC International Study of Kidney Disease in Children; MCNS minimal change nephrotic syndrome; MMF mycophenolate mofetil

classification for the quality of evidence and strength of recommendations has been provided in additional file 4 .

These key elements of the management of childhood SNSS included case definition, genetic testing, diet therapy, treatment of an initial episode of SSNS with steroids, treatment of relapsing SSNS with steroids, steroid therapy in FRNS and SDNS in children, treatment of FRNS and SDNS with steroid-sparing agents, renal biopsy, and vaccination in these children.

A set of strengths were noted in our work. First, we used a comprehensive search strategy to identify potentially relevant CPGs and performed quality assessment using the AGREE II tool by an expert specialized clinical team of pediatric nephrologists, general pediatricians, a clinical pharmacist, a renal pathologist, and a specialized nurse guided by two pediatricians with expertise in CPG methodologies, which adds a layer of strength to the AGREE II assessment. The results of this review can be used as a basis for CPG development or adaptation projects for the management of children with SSNS.

Furthermore, the results of our study propose the importance of including the AGREE II criteria in the capacity building of clinicians to guide their decisions in selecting CPGs for use in their daily practice.

Our study also has several limitations. First, some disadvantages of AGREE II have been addressed in the "AGREE-REX" (Recommendation EXcellence) tool, which addresses the clinical credibility of the CPG recommendations [31]. The selection of $70 \%$ as a cutoff point for standard domain ratings is another potential limitation as the original AGREE II does not mandate such a cutoff, but similar studies have also suggested so [22, 23].

Other limitations, apart from those imposed by the AGREE II, include the following: (i) only English or Arabic language CPGs may have resulted in the exclusion of relevant CPGs intended for use in non-Englishspeaking and non-Arabic healthcare settings; (ii) this review mainly focused on CPGs for management of SSNS in children and did not evaluate other subcategories of nephrotic syndrome in children as it was out of the scope of this study.

\section{Implications for practice: guidance for clinical guideline uptake}

The adaptation of CPGs has been identified as a valid alternative to de novo development, which is a resource-extensive process [13]. Evidence-based practice initiatives in several countries in our region have opted to utilize CPG adaptation rather than de novo development [11, 12]. Several CPG formal adaptation methodologies are presently available and could be further customized to local contexts [13]. Studies similar to our study could provide information on relevant CPG adaptation projects for the same health topics, especially for groups with little experience in using the AGREE II instrument.

This critical appraisal highlights the importance of quality assessment of CPGs by clinicians to ensure the transparency and strength of the CPG development process according to international CPG standards and support the best practice for children with SNSS. We recommend incorporating the AGREE II appraisal of CPGs in the capacity building of pediatricians and nephrologists.

\section{Conclusions}

The methodological quality of the KDIGO CPG was superior, followed by JSPN and AAP CPGs. Recommendations including the case definition, genetic testing, diet therapy, treatment of an initial episode of SSNS with steroids, treatment of relapsing SSNS with steroids, steroid therapy in FRNS and SDNS in children, treatment of FRNS and SDNS with steroid-sparing agents, renal biopsy, and vaccination in children with SSNS. 


\section{Abbreviations}

AGREE: Appraisal of Guidelines for REsearch \& Evaluation; AAP: American Academy of Pediatrics; CPG: Clinical Practice Guideline; JSPN: Japanese Society of Pediatric Nephrology; KDIGO: Kidney Disease: Improving Global Outcomes; SR: Systematic review; SSNS: Steroid-sensitive nephrotic syndrome

\section{Supplementary Information}

The online version contains supplementary material available at https://doi. org/10.1186/s13643-021-01666-w.
Additional file 1. Search strategy.
Additional file 2. PICAR statement.
Additional file 3. PRISMA checklist.
Additional file 4. Evidence-Base Classifications.

\section{Acknowledgements}

We would like to thank the Saudi Society of Nephrology and Transplantation (SSN\&T) for the logistic support in the parallel training workshops conducted as part of this project and financial support for the publication fees of this article. The society did not influence any phase of this research project. This study was supported by King Saud University, Deanship of Scientific Research, Research Chair for Evidence-Based Health Care and Knowledge Translation, Riyadh, Saudi Arabia. Furthermore, we would like to extend our thanks to the Researchers Support \& Services Unit at King Saud University for technical support and the King Saud University Medical City for logistics and resources.

\section{Authors' contributions}

All authors have made substantial contributions and provided final approval of the conception, drafting, and final version of this manuscript. YSA, RA, and KA conceptualized and designed the study. YSA, RA, KA, MA, NA, WA, and RJ contributed to the search, screening, and critical appraisal of guidelines. YSA WA, NA, RA, and KA wrote the first draft of the manuscript. YSA, RA, KA, WA, and NA analyzed and interpreted the data. KA, YA, and RA supervised the procedures in the study and reviewed the drafts and final version of this manuscript. All authors have read and approved the final version of the manuscript.

\section{Authors' information}

The authors are researchers in the relevant fields of Evidence-based healthcare, systematic reviews, health services research, and clinical practice guideline methodology (YSA, RA, and MH), General Pediatrics (KA, YSA, RA, $\mathrm{RB}, \mathrm{MHT}$, and $\mathrm{MH}$ ), Pediatric Nephrology (KA, JK, MA, NA, RR, SKS, WA, AA, $A A$, and $A A)$, Pathology (TA), Clinical Pharmacy (MA), and Nursing (RJ).

\section{Funding}

None.

\section{Availability of data and materials}

Not applicable.

\section{Declarations}

\section{Ethics approval and consent to participate}

Not applicable.

\section{Consent for publication}

Not applicable.

\section{Competing interests}

None.

\section{Author details}

${ }^{1}$ Pediatric Nephrology Unit, Pediatrics Department, College of Medicine, King Saud University, Riyadh, Saudi Arabia. ${ }^{2}$ Saudi Society of Nephrology and Transplantation (SSN\&T), Riyadh, Saudi Arabia. ${ }^{3}$ Pediatric Endocrinology Unit, Pediatrics Department, College of Medicine, King Saud University, Riyadh, Saudi Arabia. ${ }^{4}$ Department of Pediatric Nephrology, Prince Sultan Military
Medical City, Riyadh, Saudi Arabia. ${ }^{5}$ College of Medicine, Alfaisal University, Riyadh, Saudi Arabia. ${ }^{6}$ Nephrology Section, Pediatrics Department, King Faisal Specialist Hospital and Research Center, Riyadh, Saudi Arabia. ${ }^{7}$ Pediatric Neurology Unit, Pediatrics Department, King Khalid University Hospital, King Saud University Medical City, Riyadh, Saudi Arabia. ${ }^{8}$ Prince Sultan Military Medical City, Riyadh, Saudi Arabia. ${ }^{9}$ Pediatric Nephrology Division, Department of Pediatrics, Pediatric Nephrology Center of Excellence Faculty of Medicine, King Abdulaziz University, Jeddah, Saudi Arabia. ${ }^{10}$ Pharmacy Services Department, King Khalid University Hospital, King Saud University Medical City, Riyadh, Saudi Arabia. ${ }^{11}$ General Pediatrics Unit, Pediatrics Department, King Khalid University Hospital, King Saud University Medical City, Riyadh, Saudi Arabia. ${ }^{12}$ Department of Pathology and Laboratory Medicine, King Faisal Specialist Hospital and Research Center, Riyadh, Saudi Arabia. ${ }^{13}$ Pediatrics Department, College of Medicine, King Saud University, Riyadh, Saudi Arabia. ${ }^{14}$ Department of Pediatric Nephrology, Pediatrics Hospital, King Saud Medical City, Riyadh, Saudi Arabia. ${ }^{15}$ Imam Mohammed Bin Saud University, Riyadh, Saudi Arabia. ${ }^{16}$ Pediatric Intensive Care Unit, Pediatric Department, College of Medicine, King Saud University, Riyadh, Saudi Arabia. ${ }^{17}$ Pediatric Nephrology, Medanta, The Medicity, Gurgaon, India. ${ }^{18}$ Pediatric Nephrology, Akron Children's Hospital, Akron, OH, USA. ${ }^{19}$ Ward $11 \mathrm{~B}$ and Day Care, Pediatrics-Nursing, King Khalid University Hospital, King Saud University Medical City, Riyadh, Saudi Arabia. ${ }^{20}$ Pediatrics Department, King Khalid University Hospital, Riyadh, Saudi Arabia. ${ }^{21}$ Clinical Practice Guidelines Unit, Quality Management Department, King Saud University Medical City, Riyadh, Saudi Arabia. ${ }^{22}$ Research Chair for Evidence-Based Health Care and Knowledge Translation, King Saud University, Riyadh, Saudi Arabia. ${ }^{23}$ Alexandria Center for Evidence-Based Clinical Practice Guidelines, Alexandria University, Alexandria, Egypt.

Received: 23 October 2020 Accepted: 5 April 2021

Published online: 10 May 2021

\section{References}

1. Noone DG, lijima K, Parekh R. Idiopathic nephrotic syndrome in children. Lancet. 2018;392(10141):61-74. https://doi.org/10.1016/S01406736(18)30536-1.

2. Glomerular Diseases (GD) - KDIGO [Internet]. Kdigo.org. 2021 [cited 12 April 2021]. Available from: https://kdigo.org/guidelines/gd/.

3. Koskimies O, Vilska J, Rapola J, Hallman N. Long-term outcome of primary nephrotic syndrome. Arch Dis Child. 1982;57(7):544-8. https://doi.org/10.113 6/adc.57.7.544.

4. D’Agati VD, Kaskel FJ, Falk RJ. Focal segmental glomerulosclerosis. N Engl J Med. 2011;365(25):2398-411. https://doi.org/10.1056/NEJMra1106556.

5. Chanchlani R, Parekh RS. Ethnic differences in childhood nephrotic syndrome. Front Pediatr. 2016:4:39. https://doi.org/10.3389/fped.2016.00039.

6. Alfakeekh K, Azar M, Sowailmi BA, Alsulaiman S, Makdob SA, Omair A, et al. Immunosuppressive burden and risk factors of infection in primary childhood nephrotic syndrome. J Infect Public Health. 2019;12(1):90-4 https://doi.org/10.1016/j.jiph.2018.09.006.

7. Alharthi AA. Patterns of childhood steroid-sensitive and steroid-resistant nephrotic syndrome in Saudi children. Clin Pediatr (Phila). 2017;56(2):177-83. https://doi.org/10.1177/0009922816645521.

8. Kari JA. Pediatric renal diseases in the Kingdom of Saudi Arabia. World J Pediatr. 2012;8(3):217-21. https://doi.org/10.1007/s12519-012-0360-6.

9. Alhasan K, Aloudah NM, Bakhit AA, Alhamad YM, Chihabeddine KM, Alfaadhel TA, et al. Renal histopathology spectrum in children with kidney diseases in Saudi Arabia, 1998-2017. Saudi Med J. 2020;41(4):369-75. https:// doi.org/10.15537/smj.2020.4.24999.

10. Institute of Medicine. Graham R, Mancher M, Miller Wolman D, et al., editors (US) Committee on standards for developing trustworthy clinical practice guidelines. Available from: https://www.ncbi.nlm.nih.gov/books/NBK209539/. Clinical practice guidelines we can trust. Washington, (DC): National Academies Press (US); 2011. doi: https://doi.org/10.17226/13058

11. Amer YS, Wahabi HA, Abou Elkheir MM, Bawazeer GA, lqbal SM, Titi MA, et al. Adapting evidence-based clinical practice guidelines at university teaching hospitals: A model for the eastern Mediterranean Region. J Eval Clin Pract. 2019;25(4):550-60. https://doi.org/10.1111/jep.12927.

12. Amer YS, Elzalabany MM, Omar TI, Ibrahim AG, Dowidar NL. The 'Adapted ADAPTE': an approach to improve utilization of the ADAPTE guideline adaptation resource toolkit in the Alexandria Center for Evidence-Based 
Clinical Practice Guidelines. J Eval Clin Pract. 2015;21(6):1095-106. https:// doi.org/10.1111/jep.12479.

13. Wang Z, Norris $S L$, Bero $L$. The advantages and limitations of guideline adaptation frameworks. Implement Sci. 2018;13(1):72. https://doi.org/10.11 86/s13012-018-0763-4.

14. Brouwers MC, Kho ME, Browman GP, Burgers JS, Cluzeau F, Feder G, et al. AGREE II: advancing guideline development, reporting and evaluation in health care. CMAJ Can Med Assoc J. 2010;182(18):E839-42. https://doi.org/1 0.1503/cmaj.090449.

15. Brouwers MC, Spithoff K, Lavis J, Kho ME, Makarski J, Florez ID. What to do with all the AGREEs? The AGREE portfolio of tools to support the guideline enterprise [published online ahead of print, May 29 2020]. J Clin Epidemiol. 2020;S0895-4356(20):30111-6. https://doi.org/10.1016/j.jclinepi.2020.05.025.

16. Siering U, Eikermann M, Hausner E, Hoffmann-Eßer W, Neugebauer EA. Appraisal tools for clinical practice guidelines: a systematic review. PLOS ONE. 2013;8(12):e82915. https://doi.org/10.1371/journal.pone.0082915.

17. Johnston A, Kelly SE, Hsieh SC, Skidmore B, Wells GA. Systematic reviews of clinical practice guidelines: a methodological guide. J Clin Epidemiol. 2019; 108:64-76. https://doi.org/10.1016/j.jclinepi.2018.11.030

18. Alhassan K, Al-Khalifah R, Aloufi MS, Almaiman W, Hamad M, Abdulmajeed NF, Al Salloum A, Aljelaifa M, Kari J, Bassrawi R, Al Hussain T, Alherbish A, Al Talhi A, Joseph R, Amer Y. A critical appraisal of clinical practice guidelines for the treatment or management of idiopathic steroid-sensitive nephrotic syndrome (SSNS) in children: systematic review and assessment using the Appraisal of Guidelines for REsearch and Evaluation (AGREE II) Instrument. PROSPERO 2020 CRD42020197511. Available from: https://www.crd.york.ac. uk/prospero/display_record.php?ID=CRD42020197511.

19. Vernooij RW, Sanabria AJ, Solà I, Alonso-Coello P, Martínez GL. Guidance for updating clinical practice guidelines: a systematic review of methodological handbooks. Implement Sci. 2014;9(1):3. https://doi.org/10.1186/1748-5908-9-3.

20. Login - AGREE Enterprise website. Agreetrust.org. [cited 14 August 2019]. Available from: https://www.agreetrust.org/my-agree/

21. Altokhais Tl, Al-Obaid OA, Kattan AE, Amer YS. CPG collaborative groups. Assessment of implementability of an adapted clinical practice guideline for surgical antimicrobial prophylaxis at a tertiary care university hospital. J Eval Clin Pract. 2017;23(1):156-64. https://doi.org/10.1111/jep.12658.

22. Eady EA, Layton AM, Sprakel J, Arents BWM, Fedorowicz Z, van Zuuren EJ. AGREE II assessments of recent acne treatment guidelines: how well do they reveal trustworthiness as defined by the U.S. Institute of Medicine criteria? Br J Dermatol. 2017;177(6):1716-25. https://doi.org/1 $0.1111 / \mathrm{bjd} .15777$.

23. Anwer MA, Al-Fahed OB, Arif SI, Amer YS, Titi MA, Al-Rukban MO. Quality assessment of recent evidence-based clinical practice guidelines for management of type 2 diabetes mellitus in adults using the AGREE ॥ instrument. J Eval Clin Pract. 2018;24(1):166-72. https://doi.org/10.1111/ jep.12785.

24. Moher D, Liberati A, Tetzlaff J, Altman DG. The PRISMA Group. Preferred reporting items for systematic reviews and meta-analyses: the PRISMA statement. PLOS Med. 2009;6(7):e1000097. https://doi.org/10.1371/journal. pmed.1000097.

25. Gipson DS, Massengill SF, Yao L, Nagaraj S, Smoyer WE, Mahan JD, et al. Management of childhood onset nephrotic syndrome. Pediatrics. 2009; 124(2):747-57. https://doi.org/10.1542/peds.2008-1559.

26. Nishi S, Ubara Y, Utsunomiya Y, Okada K, Obata Y, Kai H, et al. Evidencebased clinical practice guidelines for nephrotic syndrome 2014. Clin Exp Nephrol. 2016;20(3):342-70. https://doi.org/10.1007/s10157-015-1216-X.

27. Ishikura K, Matsumoto S, Sako M, Tsuruga K, Nakanishi K, Kamei K, et al. Clinical practice guideline for pediatric idiopathic nephrotic syndrome 2013: medical therapy. Clin Exp Nephrol. 2015;19(1):6-33. https://doi.org/10.1007/ s10157-014-1030-x.

28. Kaku Y, Ohtsuka Y, Komatsu Y, Ohta T, Nagai T, Kaito H, et al. Clinical practice guideline for pediatric idiopathic nephrotic syndrome 2013: general therapy. Clin Exp Nephrol. 2015;19(1):34-53. https://doi.org/10.1007/s10157014-1031-9.

29. Cattran DC, Feehally J, Cook HT, Liu ZH, Fervenza FC, Mezzano SA, et al. Kidney disease: improving global outcomes (KDIGO) glomerulonephritis work group. KDIGO clinical practice guideline for glomerulonephritis. Kidney Int Suppl. 2012;2(2):139-274.

30. Kdigo.org. Glomerulonephritis (GN) - KDIGO; 2020 [cited Jul 10 2020]. Available from: https://kdigo.org/quidelines/gn/.
31. Brouwers MC, Spithoff K, Kerkvliet K, Alonso-Coello P, Burgers J, Cluzeau F, et al. Development and validation of a tool to assess the quality of clinical practice guideline recommendations. JAMA Netw Open. 2020;3(5):e205535. https://doi.org/10.1001/jamanetworkopen.2020.5535.

32. Alonso-Coello P, Irfan A, Solà I, Gich I, Delgado-Noguera M, Rigau D, et al. The quality of clinical practice guidelines over the last two decades: a systematic review of guideline appraisal studies. Qual Saf Health Care. 2010; 19(6):e58. https://doi.org/10.1136/qshc.2010.042077.

33. Brosseau L, Rahman P, Poitras S, Toupin-April K, Paterson G, Smith C, et al. A systematic critical appraisal of non-pharmacological management of rheumatoid arthritis with Appraisal of Guidelines for Research and Evaluation II. PLOS ONE. 2014;9(5):e95369. https://doi.org/10.1371/journal. pone.0095369.

\section{Publisher's Note}

Springer Nature remains neutral with regard to jurisdictional claims in published maps and institutional affiliations.

Ready to submit your research? Choose BMC and benefit from:

- fast, convenient online submission

- thorough peer review by experienced researchers in your field

- rapid publication on acceptance

- support for research data, including large and complex data types

- gold Open Access which fosters wider collaboration and increased citations

- maximum visibility for your research: over $100 \mathrm{M}$ website views per year

At BMC, research is always in progress.

Learn more biomedcentral.com/submissions 